\title{
Production of lipolytic enzymes by bacteria isolated from biological effluent treatment systems
}

\author{
GRACIANE FURINI ${ }^{1}$, JUSSARA S. BERGER ${ }^{1}$, JOSÉ A.M. CAMPOS ${ }^{1}$, \\ SUELI T. VAN DER SAND ${ }^{1}$ and JOSÉ C. GERMANI ${ }^{2}$

\begin{abstract}
${ }^{1}$ Departamento de Microbiologia, Imunologia e Parasitologia, Instituto de Ciências Básicas da Saúde, Universidade Federal do Rio Grande do Sul, Rua Sarmento Leite, 500, 90050-170 Porto Alegre, RS, Brazil

${ }^{2}$ Departamento de Produção de Matéria Prima, Faculdade de Farmácia, Universidade Federal do Rio Grande do Sul, Avenida Ipiranga, 2752, 90610-000 Porto Alegre, RS, Brazil
\end{abstract}

Manuscript received on November 24, 2017; accepted for publication on March 26, 2018

\begin{abstract}
This work aimed to evaluate the production of lipolytic complexes, produced by microorganisms isolated from a biological treatment system of effluents from a hotel. To select the best lipolytic microorganism for use in biotechnological processes, we tested 45 bacterial isolates recovered from the raw effluent of the hotel's restaurant waste tank. Lipase production was assayed in culture medium supplemented with olive oil and rhodamine B, incubated at $25^{\circ} \mathrm{C}$ and $30^{\circ} \mathrm{C}$ for $24 \mathrm{~h}-48 \mathrm{~h}$. Results showed 22 isolates lipase producers. All isolates were inoculated on medium without yeast extract to select the ones with highest enzyme yields. Out of these, nine isolates showed high lipase activity. The strain with the larger halo was assayed in submerged culture using an orbital shaker and a bioreactor, with three different substrates (olive oil, grape seed oil, and canola oil). Isolate G40 identified as Acinetobacter baylyi was selected to run the production assays because it showed the best result in the solid medium. In the bioreactor, maximum lipase production was obtained after $12 \mathrm{~h}$ of culture with the three substrates evaluated: $0,358 \mathrm{U} / \mathrm{mL} \cdot \mathrm{min}^{-1}$ in olive oil, $0,352 \mathrm{U} / \mathrm{mL} \cdot \mathrm{min}^{-1}$ with grapeseed oil, and $0,348 \mathrm{U} / \mathrm{mL} \cdot \mathrm{min}^{-1}$ with canola oil.
\end{abstract}

Key words: lipolytic enzymes, bacteria, submerged culture, wastewater.

\section{INTRODUCTION}

The increasing need for industrial enzymes, especially in the environmental area, is driven by the growing necessity for sustainable solutions. Estimates show that the global market for enzymes grows 6-7\% per year and that in 2017 it can reach US\$ 7 billion. Currently, the largest sector of the biotechnology industry is the production and use of

Correspondence to:Sueli Teresinha Van Der Sand

E-mail: svands@ufrgs.br enzymes from microbial origin. Filamentous fungi, yeasts, and bacteria continue to serve as one of the largest and most useful sources of many enzymes (Adrio and Demain 2014, Santos 2012, Freedonia 2014). Lipases (triacylglycerol acyl hydrolases EC 3.1.1.3) are enzymes that catalyze the hydrolysis of triacylglycerol into glycerol and fatty acids (Liu and Kokare 2017). Their production by submerged fermentation is directly related to nutritional and physicochemical factors, such as carbon and 
nitrogen sources, temperature, $\mathrm{pH}$, besides the presence of enzyme inducers such as vegetable oils (Almeida et al. 2016, Orlandelli et al. 2012). Studies with different microorganisms and substrates for the production of lipases in liquid media, can contribute to find optimal conditions to obtain high yields of enzymes, and thus reduce production costs on an industrial scale (Ochsenreither 2016, Feitosa et al. 2010). There are many lipase-producing bacteria which are commercially used, mainly from the genera Achromobacter, Alcaligenes, Burkholderia, Chromobacterium, and Pseudomonas. With the advancement of research in this area, other lipolytic bacteria were identified such as Acinetobacter and Brevibacterium (Bhosale et al. 2016, Ugras and Uzmez 2016, Sharma 2017).

The microbial biodiversity in Brazil and the possibility of using agricultural and industrial residues as substrates, justify the search for new microorganisms producing enzymes with desirable characteristics that can be applied industrially (Vitorino and Bessa 2017, Costa 2014).

The present work aims to isolate and identify lipase producing bacteria and to quantify the lipolytic activity of the bacterial isolate recovered from a biological treatment system of a hotel in the municipality of Bento Gonçalves, Rio Grande do Sul State. The effluent object of this study presents a large concentration of lipids, making it suitable for the isolation of bacteria producing lipolytic enzymes to be used in industrial biotechnological processes.

\section{MATERIALS AND METHODS}

\section{SAMPLE COLLECTION}

Samples of the effluent in the grease trap box of the hotel's restaurant were collected in sterile glass bottles, at two points: incoming crude effluent and treated effluent in the outlet box. The samples were stored on ice and taken to the laboratory for the assays.

\section{ISOLATION OF MICROORGANISMS}

The recovered samples were diluted in peptone water up to dilution $10^{-4}$. Dilutions $10^{-2}, 10^{-3}, 10^{-4}$ were inoculated on Petri dishes containing TSA agar and incubated at $25{ }^{\circ} \mathrm{C}$ and $30{ }^{\circ} \mathrm{C}$ for $48 \mathrm{~h}$. After growth, the colonies were re-isolated in TSA plates.

\section{SELECTION OF LIPASE-PRODUCING MICROORGANISMS}

Lipolytic activity was tested using culture medium proposed by Kouker and Jaeger (1987), with modifications $(0.5 \%$ peptone, $0.1 \%$ yeast extract, $0.4 \% \mathrm{NaCl}, 1.5 \%$ agar and $0.1 \%$ rhodamine $\mathrm{B}$ solution). After sterilization, $2.5 \%$ sterile olive oil was added as a carbon source. All isolates were inoculated by the spot method, and plates incubated at $25{ }^{\circ} \mathrm{C}$ and $30^{\circ} \mathrm{C}$ for up to $72 \mathrm{~h}$. The growth of the isolates was checked daily and the lipid hydrolysis confirmed by the orange fluorescence on the colonies when exposed to UV light at 350 $\mathrm{nm}$. Isolates with faster growth were reinoculated in the culture medium deprived of yeast extract, to induce olive oil uptake and thus to select the best enzyme-producing strains. Incubation took place in the same conditions as described before. The same assay was performed with canola oil and grape seed oil as a carbon source.

\section{BIOCHEMICAL IDENTIFICATION}

All isolates were submitted to the biochemical tests of oxidation/fermentation, citrate utilization, lactose and glucose fermentation, oxidase, catalase, $\mathrm{H}_{2} \mathrm{~S}$ production, indol and motility, nitrate production, methyl red (VM) and Voges-Proskauer (VP), gelatin, urea, bile esculin and cellobiose, growth on MacConkey agar and cetrimide agar.

\section{SUBMERGED CULTURE IN THE ORBITAL SHAKER}

The isolate that presented the highest fluorescence in the solid media assays, with the three different 
substrates, was tested in submerged cultures. The inoculum was made by seeding the selected isolate into a $150 \mathrm{~mL}$ Erlenmeyer flask containing $50 \mathrm{~mL}$ of culture medium as described before. The flask was maintained in an orbital shaker at $120 \mathrm{rpm}$, at $30{ }^{\circ} \mathrm{C}$ for $12 \mathrm{~h}$. From this culture, one aliquot of $2.5 \mathrm{~mL}$ was used to seed a flask with $50 \mathrm{~mL}$ of medium and incubated in an orbital shaker at 120 $\mathrm{rpm}$, at $30^{\circ} \mathrm{C}$ for $24 \mathrm{~h}$. Every two hours a $2.5 \mathrm{~mL}$ aliquot was drawn to determine the optical density (OD) at $540 \mathrm{~nm}$ and the lipase activity. For the enzyme activity, $1.5 \mathrm{~mL}$ aliquot was centrifuged at $12000 \mathrm{rpm}$ for $15 \mathrm{~min}$. The supernatant collected was frozen for further enzyme activity assays. The same procedure and conditions were performed for canola and grape seed oils.

To evaluate the effect of an emulsifier on enzyme production, $0.01 \%$ of sterile Tween 80 was added to the medium, and assays performed under the same conditions as described previously. All assays were performed in duplicate.

\section{SUBMERGED CULTURE IN THE BIOREACTOR}

The bioreactor used was a $2 \mathrm{~L}$ nominal volume BIOSTAT B (Braun) with a working volume of 1.5 $\mathrm{L}$ of the same culture medium used in the orbital shaker. The three oils were tested separately as the sole carbon source. The bioreactor was inoculated with $750 \mathrm{~mL}$ of a $12 \mathrm{~h}$ culture grown in the same medium used in the bioreactor. The running time was $24 \mathrm{~h}$ at $30^{\circ} \mathrm{C}$, aeration maintained at $1.5 \mathrm{vvm}$ with sterile air, and agitation at $300 \mathrm{rpm}$. Culture samples of $10 \mathrm{~mL}$ were taken at time zero and every two hours for $24 \mathrm{~h}$, and optical density, $\mathrm{pH}$, and lipolytic activity was determined. The same assays were performed with olive oil, canola oil, and grape seed oil. All assays done in duplicate.

\section{LIPOLYTIC ACTIVITY BY SPECTROMETRY}

Lipolytic activity was determined by spectrophotometry using p-nitrophenyl palmitate
(pNPP) as the substrate following the method described by Winkler and Stuckmann (1979). A unit of lipase (U) is the amount of enzyme releasing $1 \mu \mathrm{M}$ of p-nitrophenol (p-NP) in $1 \mathrm{~min} /$ $\mathrm{mL}$ of supernatant under assay conditions. All tests conducted in duplicate.

\section{MOLECULAR IDENTIFICATION}

The DNA extraction was performed using the boiling method. Cells grown in TSB for $18 \mathrm{~h}$ were transferred to microtubes and placed in a water bath at $100{ }^{\circ} \mathrm{C}$ for 10 minutes following centrifugation for 5 minutes at $13000 \mathrm{rpm}$ and the supernatant used. The quality of the extracted DNA was evaluated in a Nanodrop spectrophotometer. For amplification of the ribosomal DNA 16S region, the primers 8F 5' AGAGTTTGATCCTGGCTCAG 3' (Turner et al. 1999) and 1544R 5' AGAAAGGAGGTGATCCAGCC 3' (Dorsch and Stackebrandt 1992) were used. The amplification was performed in a final volume of $25 \mu \mathrm{L}$ by adding $2.5 \mu \mathrm{L}$ of buffer (10X), $1.5 \mu \mathrm{L}$ of $\mathrm{MgCl}_{2}$ (50 $\mathrm{mM}), 200 \mathrm{ng}$ of Bovine Serum Albumin (BSA), 10 pmol of each primer, $1 \mathrm{U}$ of Taq polymerase, $0.2 \mathrm{mM}$ of deoxynucleotide triphosphate, and 50 ng DNA and MilliQ water to complete the final volume. Amplification was performed with an initial denaturation at $94{ }^{\circ} \mathrm{C}$ for 5 minutes followed by 35 cycles at $94{ }^{\circ} \mathrm{C}$ for 45 seconds, $58{ }^{\circ} \mathrm{C}$ for 45 seconds and $72{ }^{\circ} \mathrm{C}$ for 1 minute and the final extension of $72^{\circ} \mathrm{C}$ for 5 minutes. The amplification product was purified using the PCR Products Purification Kit (Ludwig Biotec). Sequencing was performed at Ludwig Biotec using ABI-Prism 3500 Genetic Analyzer (Applied Biosystems) equipment. The obtained sequence was compared using the sequences stored in GenBank using the BLAST software (http://blast.ncbi.nlm.nih.gov/ Blast.cgi). 


\section{SDS-PAGE}

The molecular mass of the lipase produced by the isolate was analyzed by electrophoresis on $12 \%$ polyacrylamide gel (SDS-PAGE). Aliquots of the supernatant containing the enzyme were added to the sample buffer in a ratio of $1: 1$ and placed in a water bath at $100{ }^{\circ} \mathrm{C}$ for 5 minutes. An aliquot of $35 \mu \mathrm{L}$ of this sample was applied to the gel. Electrophoretic migration was performed in 50 $\mathrm{mM}$ Tris-glycine buffer, $100 \mathrm{~V}$, for $2 \mathrm{~h}$. Afterward, the gel was stained with silver nitrate, according to Alfenas (1998).

\section{RESULTS}

\section{SELECTION OF LIPOLYTIC MICROORGANISMS}

Of the total of 45 bacteria isolated, 22 were positive for lipase and out of these nine isolates showed lipolytic activity in the culture medium deprived of yeast extract. These nine isolates were further assayed using three different carbon sources: olive oil, canola oil, and grape seed oil. The assays were performed at $25{ }^{\circ} \mathrm{C}$ and $30{ }^{\circ} \mathrm{C}$. Isolates grown at $30{ }^{\circ} \mathrm{C}$ in all three oils showed a higher fluorescence under UV light when compared to growth at $25^{\circ} \mathrm{C}$
(Table I). The strain with the highest fluorescence on the three substrates in both temperatures was named as isolate G40 and chosen for further submerged culture assays.

\section{BIOCHEMICAL IDENTIFICATION}

All the nine isolates were Gram-negative bacteria, being four bacilli and five cocci bacilli. Three of them were identified as Enterobacter, three of the genus Burkholderia, two of the genus Acinetobacter, and one as Pseudomonas using biochemical assays. The isolate G40 identified as Acinetobacter sp., by biochemical assays, was submitted to molecular identification using 16S rDNA. The result showed 99\% of similarity with Acinetobacter baylyi.

\section{SUBMERGED CULTURE AND ENZYMATIC ACTIVITY}

Isolate $\mathrm{G} 40$ was tested in submerged culture, under orbital shaker condition, using the three carbon sources, with and without Tween 80. Results showed that isolate G40 grew faster in the presence of Tween 80 demonstrating that the concentration used was sufficient to emulsify the different oils and was non-toxic. Exponential growth was observed

TABLE I

Results of fluorescence intensity obtained by the isolates in solid medium using olive oil, grape seeds oil and canola oil as substrates. Growth at $25^{\circ} \mathrm{C}$ and $30{ }^{\circ} \mathrm{C}$ for $72 \mathrm{~h}$.

\begin{tabular}{ccccccc}
\hline Isolate & \multicolumn{3}{c}{ Olive oil } & \multicolumn{2}{c}{ Grape seed oil } & \multicolumn{2}{c}{ Canola oil } \\
& $\mathbf{2 5}{ }^{\circ} \mathbf{C}$ & $\mathbf{3 0}{ }^{\circ} \mathbf{C}$ & $\mathbf{2 5}^{\circ} \mathbf{C}$ & $\mathbf{3 0}^{\circ} \mathbf{C}$ & $\mathbf{2 5}^{\circ} \mathbf{C}$ & $\mathbf{3 0}^{\circ} \mathbf{C}$ \\
\hline G33 & + & +++ & + & +++ & + & ++ \\
G34 & ++ & +++ & + & ++ & + & +++ \\
G35 & + & +++ & ++ & +++ & + & ++ \\
G39 & + & ++ & + & ++ & + & + \\
G40 & ++ & +++ & ++ & +++ & ++ & ++ \\
G41 & + & ++ & + & ++ & + & ++ \\
G49 & + & ++ & - & + & + & ++ \\
G56 & + & + & - & + & - & + \\
G57 & + & + & + & + & + & + \\
\hline
\end{tabular}

Fluorescence intensity: (+) low intensity, $(++)$ medium intensity, $(+++)$ high intensity. 
in the first $2 \mathrm{~h}$ in the presence of Tween 80 followed by the stationary phase through the $24 \mathrm{~h}$ (Fig. 1).

G40 grown in culture medium in the orbital shaker showed higher enzymatic activity with Tween 80 as emulsifier (Fig. 2). The maximum enzymatic activity with the three oils in the conditions tested was observed at $16 \mathrm{~h}$ of culture. The assay using olive oil as the carbon source and Tween 80 showed the highest enzymatic activity of $0.141 \mathrm{U} / \mathrm{mL} \cdot \mathrm{min}^{-1}$, followed by the grape seed oil with $0.113 \mathrm{U} / \mathrm{mL} \cdot \mathrm{min}^{-1}$ and $0.079 \mathrm{U} / \mathrm{mL} \cdot \mathrm{min}^{-1}$ of canola oil. The enzymatic activity in the culture media of the three oils, deprived of Tween 80, showed similar values among them, although with a much lower lipase production (Fig. 2).

Table II shows the enzymatic activity and cell growth of isolate G40 in the bioreactor. It is possible to observe an exponential growth of the cells in the first two hours, with enzymatic activity improving in the stationary phase. The best enzymatic activity for isolate G40 was observed at $12 \mathrm{~h}$ for the three substrates. Olive oil reached a high production already at $6 \mathrm{~h}$ and got improving until $12 \mathrm{~h}$. Olive oil showed the better enzymatic activity with $0.358 \mathrm{U} / \mathrm{mL} \cdot \mathrm{min}^{-1}$, followed by grape seed oil with $0.352 \mathrm{U} / \mathrm{mL} \cdot \mathrm{min}^{-1}$ and canola oil with $0.348 \mathrm{U} / \mathrm{mL} \cdot \mathrm{min}^{-1}$ (Fig. 3 and Table II). The results obtained in the bioreactor were much higher than the ones observed in the shaker (Figs. 2 and 3) with an improvement of $253.90 \%$ for olive oil, $311.5 \%$ for grape seed oil and $440.5 \%$ for canola oil.

\section{DETERMINATION OF MOLECULAR WEIGHT}

Fig. 4 shows the result obtained in the SDS-Page gel of the enzyme crude extract. The molecular weight of the enzyme observed was approximately of $35 \mathrm{kDa}$.

\section{DISCUSSION}

The nine strains isolated, of the genera Enterobacter, Burkholderia, Acinetobacter, and Pseudomonas, from the grease trap tank, represent a small fraction of the enormous diversity of lipolytic bacteria that can be recovered from the environment for biotechnological applications.

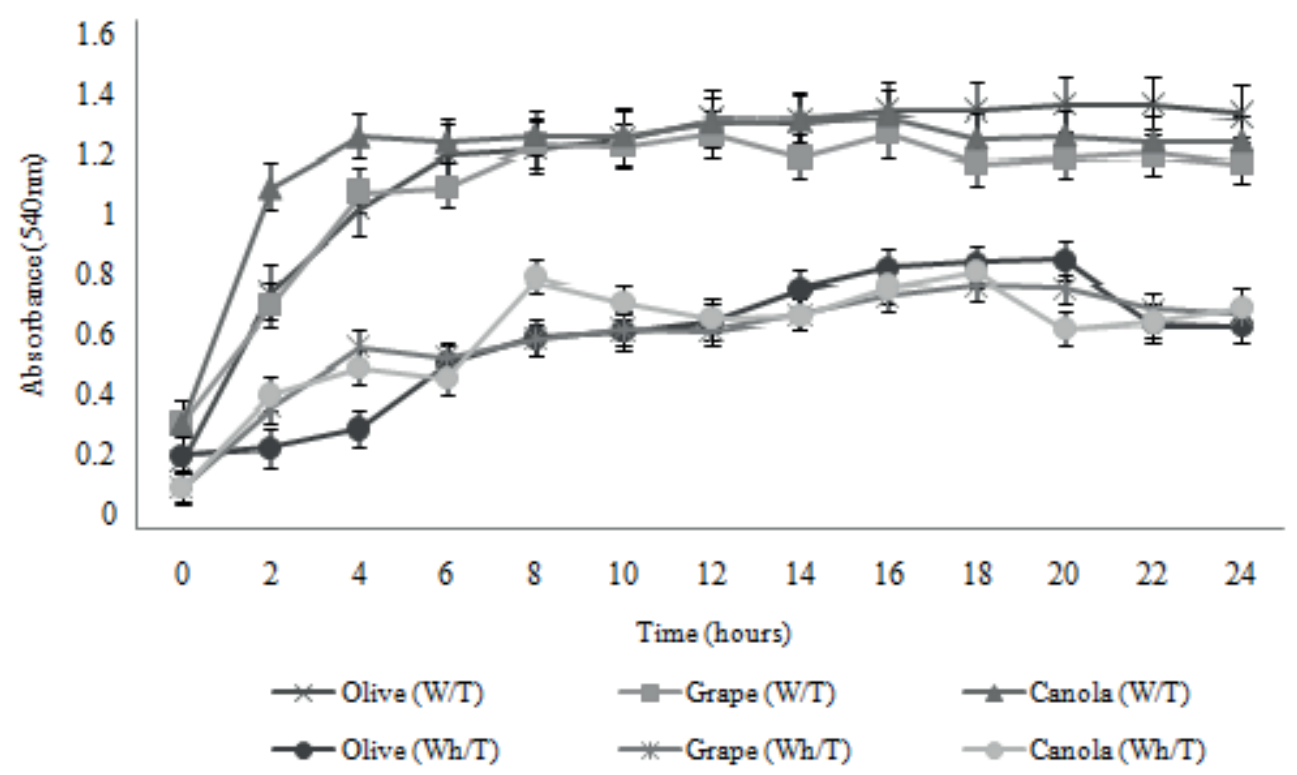

Figure 1 - G40 isolate growth curves in submerged culture with olive oil, grape seed oil, and canola oil as carbon source, with and without the addition of Tween 80 . The experiment was performed in orbital shaker, at $30^{\circ} \mathrm{C}$ for $24 \mathrm{~h}$. 
TABLE II

Comparison among cell growth of isolate $\mathbf{G 4 0}$ and its enzymatic activity. Experiment was performed in the bioreactor, at $30^{\circ} \mathrm{C}$ for $24 \mathrm{~h}$.

\begin{tabular}{ccccccc}
\hline Time $^{1}$ & \multicolumn{2}{c}{ Grape seed oil } & \multicolumn{2}{c}{ Olive oil } & \multicolumn{2}{c}{ Canola oil $^{2}$} \\
& Growth $^{2}$ & $\mathbf{E A}^{3}$ & Growth $^{2}$ & $\mathbf{E A}^{3}$ & Growth $^{2}$ & EA $^{3}$ \\
\hline 0 & 0.496 & 0.126 & 0.298 & 0.119 & 0.647 & 0.11 \\
2 & 1.288 & 0.143 & 1.534 & 0.135 & 1.489 & 0.22 \\
4 & 1.335 & 0.172 & 1.46 & 0.146 & 1.526 & 0.304 \\
6 & 1.35 & 0.252 & 1.552 & 0.348 & 1.521 & 0.287 \\
8 & 1.358 & 0.253 & 1.564 & 0.351 & 1.52 & 0.33 \\
10 & 1.383 & 0.308 & 1.574 & 0.354 & 1.531 & 0.342 \\
12 & 1.38 & 0.352 & 1.576 & 0.358 & 1.534 & 0.348 \\
14 & 1.382 & 0.334 & 1.574 & 0.309 & 1.531 & 0.236 \\
16 & 1.376 & 0.325 & 1.576 & 0.234 & 1.529 & 0.194 \\
18 & 1.384 & 0.222 & 1.575 & 0.22 & 1.49 & 0.179 \\
20 & 1.382 & 0.173 & 1.576 & 0.173 & 1.459 & 0.244 \\
22 & 1.39 & 0.213 & 1.561 & 0.209 & 1.457 & 0.236 \\
24 & 1.377 & 0.227 & 1.473 & 0.271 & 1.436 & 0.254 \\
$\mathrm{SD}^{4}$ & 0.243 & 0.074 & 0.349 & 0.09 & 0.239 & 0.069 \\
\hline
\end{tabular}

${ }^{1}$ Hour; ${ }^{2}$ Absorbance $(540 \mathrm{~nm}) ;{ }^{3}$ EA- enzyme activity (U/mL. $\left.\mathrm{min}^{-1}\right) ;{ }^{4}$ Standard Deviation (SD).

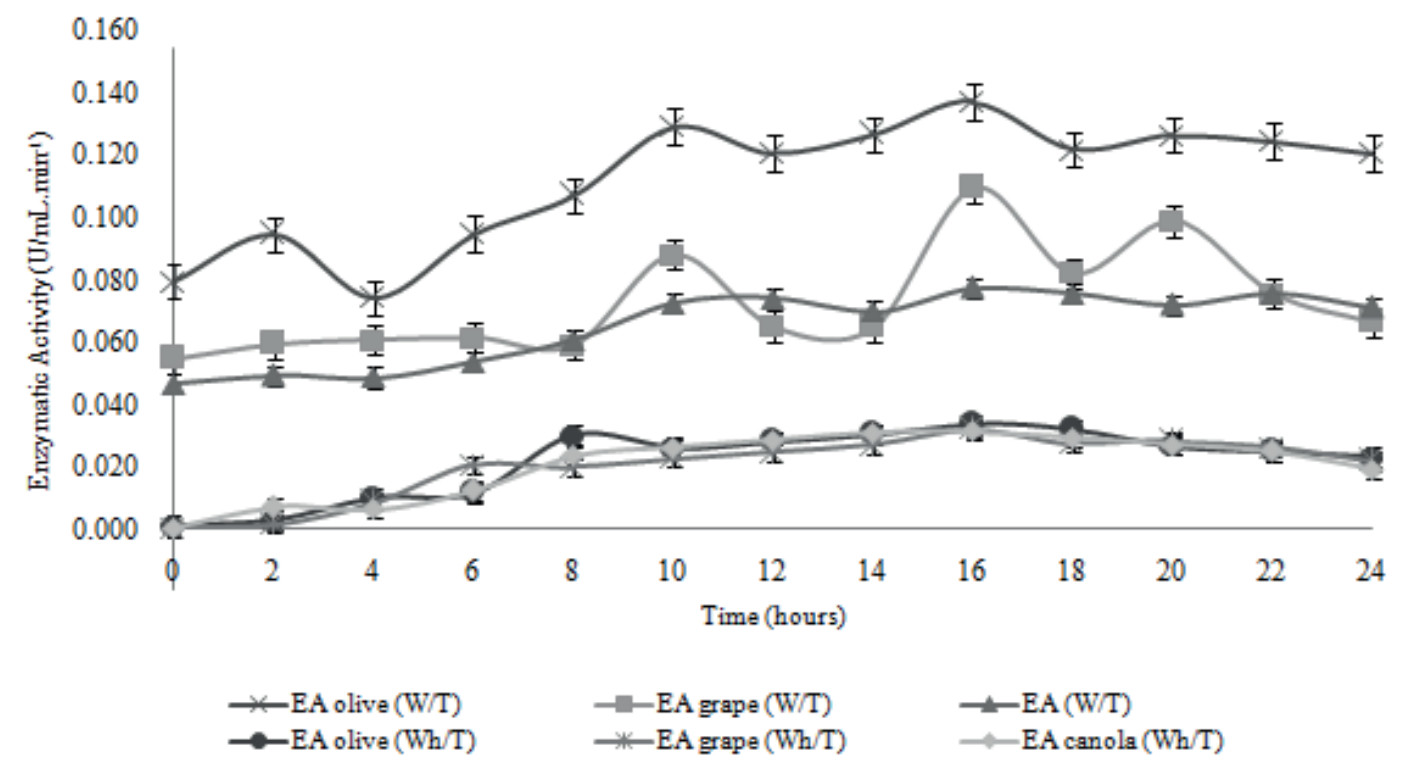

Figure 2 - Enzymatic activities produced by isolate G40 using olive oil, grape seed oil, and canola oil as the main carbon source, with and without the addition of Tween 80. Experiment performed in the orbital shaker at $30^{\circ} \mathrm{C}, 120 \mathrm{rpm}$ for $24 \mathrm{~h}$. 


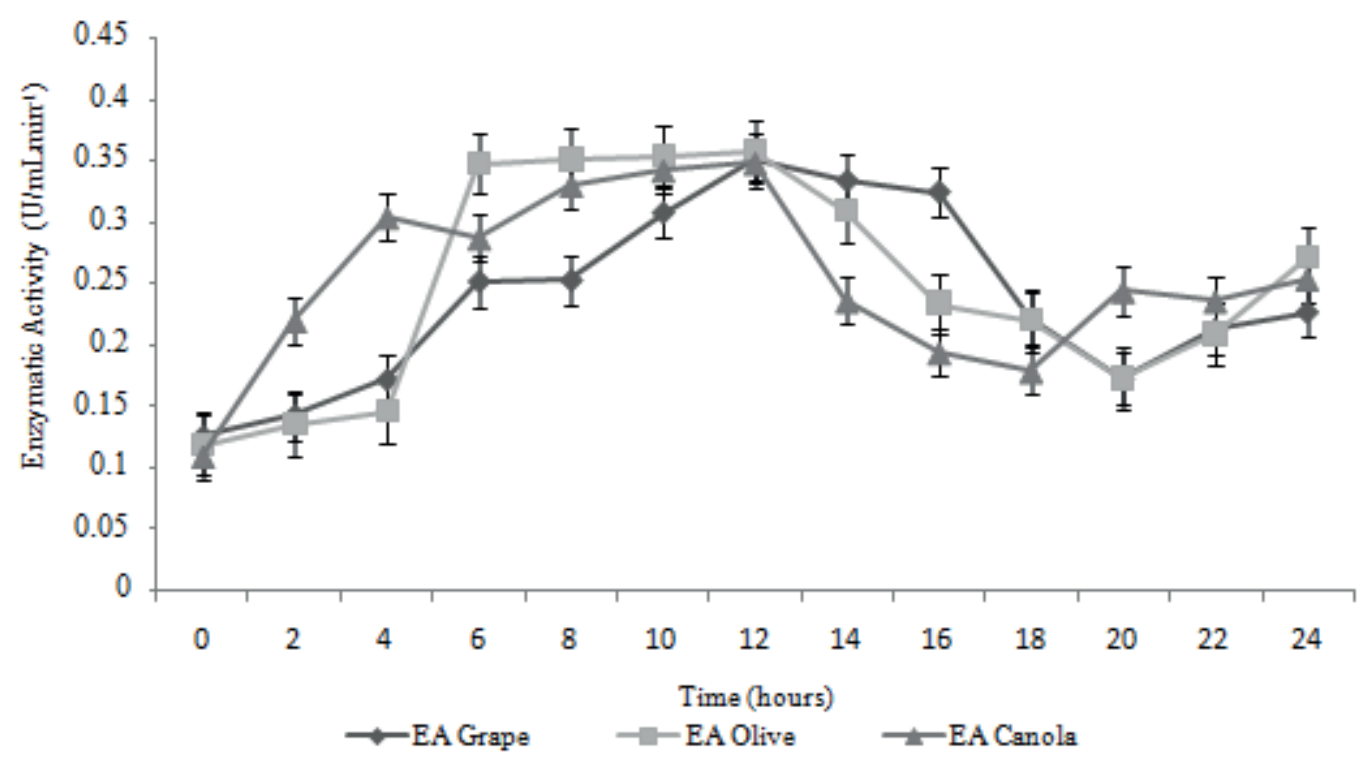

Figure 3 - Enzymatic activity produced by isolate G40 using olive oil, grape seed oil, and canola oil as the main carbon source, with Tween 80 . Experiment performed in the bioreactor at $30{ }^{\circ} \mathrm{C}$, agitation fixed at $300 \mathrm{rpm}$, aeration rate of $1.5 \mathrm{vvm}$, for $24 \mathrm{~h}$.

Musa and Tayo (2012) working with soil samples contaminated with various oils, spoiled food, and other residues identified and characterized 13 genera with lipolytic activity. The bacterial genera obtained were: Acinetobacter sp., Yersinia sp., Arthrobacter sp., Brevibacterium sp., Staphylococcus sp., Aeromonas sp., Acidomonas sp., Lactobacillus sp., Bacillus sp., Streptococcus sp., Bifidobacterium sp., Acetobacterium sp., and Citrobacter sp.

Ankit et al. (2011) investigating lipolytic microorganisms for industrial use, isolated species of lipolytic bacteria from the genera Pseudomonas sp. and Bacillus sp. from highly contaminated water samples of several rivers in the Bhopal region of India. Odeyemi et al. (2013) examining microorganisms capable of use palm oil as substrate, found 32 lipolytic bacteria grouped in the genera Enterococcus sp., Escherichia sp., Klebsiella sp., Pseudomonas sp., Serratia sp. and Staphylococcus sp., isolated from a restaurant wastewater trap tank.

The nine lipolytic strains selected in this work were Gram-negative bacteria, which is in agreement with the research of several authors, which affirm that the majority of lipolytic bacteria found in nature are Gram-negative (Ramnath et al. 2017, Alhamdani and Alkabbi 2017, Dharmsthiti and Kuhasuntissak 1998). Although some lipolytic bacteria are Gram-positive, as is the case of the genera Bacillus sp., Staphylococcus sp. and Clostridium sp., its lipolytic activity is less expressive than that of Gram-negative bacteria (Rousenau and Jaeger 2000).

Bacterial extracellular lipases are influenced by nutritional and physiological factors such as temperature, $\mathrm{pH}$, and carbon sources. In this work, the optimum temperature for the production of lipases was $30{ }^{\circ} \mathrm{C}$. However, some authors found that bacterial lipases may exhibit optimal production activity at low and high temperatures, as shown by the work of Ugras and Uzmez (2016), where the maximum enzyme activity was detected at $40{ }^{\circ} \mathrm{C}$. On the other hand, Pratuandejkul and Dharmsthiti (2000) working with Acinetobacter calcoaceticus isolated from raw milk obtained the maximum lipolytic activity after $48 \mathrm{~h}$ of culture at 


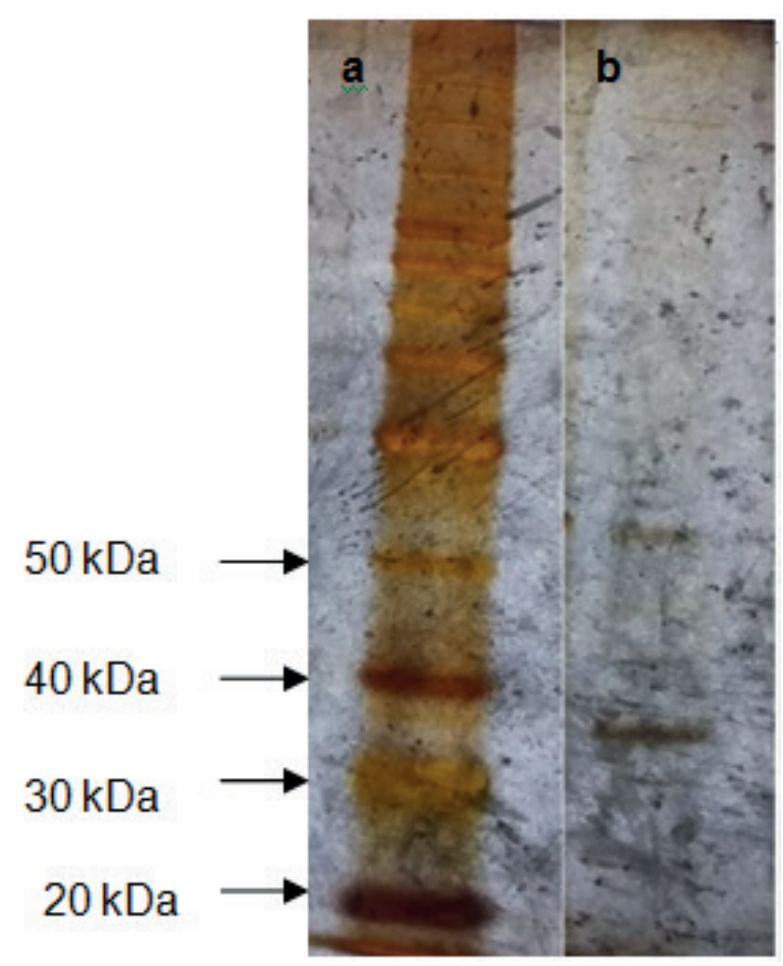

Figure 4 - Polyacrylamide denaturing gel (12\% SDS-PAGE). a: molecular weight marker, b: crude extract of the enzyme. The gel was stained with silver nitrate.

$15^{\circ} \mathrm{C}$. The observed activity value was three times higher than the one found after $24 \mathrm{~h}$ of cultivation at $30^{\circ} \mathrm{C}$. These findings emphasize the importance of further studies of enzymatic production at different temperatures, pursuing higher yields and productivity.

The lipase activity in this study was evaluated in the time interval between 0 to $24 \mathrm{~h}$ of culture. The results show that in the orbital shaker the maximum production was reached after $16 \mathrm{~h}$ at $30{ }^{\circ} \mathrm{C}$, even though in the bioreactor it occurred after $12 \mathrm{~h}$ of cultivation at the same temperature. This result is similar to that found by Anbu et al. (2011) working with Acinetobacter juniide isolated from soil contaminated with oil in South Korea, where the best enzymatic activity was observed after $12 \mathrm{~h}$ of incubation at $30^{\circ} \mathrm{C}$. Gururaj et al. (2016), working with a strain of Acinetobacter sp., obtained the maximum enzymatic activity after 16 $\mathrm{h}$ of incubation at the temperature of $30^{\circ} \mathrm{C}$.
The values of maximum lipolytic activity found in the present study are noteworthy since the isolate G40 produced lipase in $12 \mathrm{~h}$ of growth in the bioreactor at $30{ }^{\circ} \mathrm{C}$. Therefore, it showed an important characteristic for industrial purposes since the preferred strains are the ones that deliver higher enzymatic activity in the shortest time possible (Niyonzima et al. 2014, Orlandelli 2012).

One of the most important factors for the increase in lipolytic activity is the carbon source, because lipases are of the inductive type, and their preferred substrates are longchain monounsaturated fatty acids (more than ten carbons), such as oleic acid (C18:1) found in greater quantity in olive oil $(78 \%)$. The amount of oleic acid in the other oils tested in this work is $56 \%$ in canola oil and $9 \%$ in grape seed oil. Several studies confirm a high production of lipase in culture media in the presence of olive oil at a concentration of $0.1 \%$ to 3\% (Feitosa et al. 2010, Sooch and Kauldhar 2013, Iqbal and Rehman 2015) which corroborate to the results obtained in the present work. Quian and Chun-Yun (2009) in their studies reported a $4 \%$ increase in lipase activity with olive oil in the culture medium. Nwachukwu et al. (2017) compared several natural oils, olive oil palm oil, peanut oil, soybean oil and crude oil. The results with olive oil showed the higher lipolytic activity compared to other oils, and $0.8 \%$ olive oil concentration resulted in an increase in lipase production by $30 \%$. The work of Vishnupriya et al. (2010) and Essakiraj et al. (2010) also demonstrated the ability of olive oil as the best source of carbon for bacterial lipase production when compared to other oils. Dandavate et al. (2009) evaluated the effect of castor, olive, corn and peanut oils on lipase production by bacteria of the genus Burkholderia. The best production was observed in the cultivation of olive oil. Rodriguez et al. (2006) observed that the use of corn oil, almond oil, peanut oil, grape seed oil, sunflower oil and olive oil to supplement the sugarcane bagasse, induced the production of high 
rates of lipase by Rhizopus homothallicus. Kobori and Jorge (2005) compared several vegetable oils such as olive, soybean, canola, sunflower, and cotton seed as substrates for lipase. They found that among these oils, olive oil promoted the maximum production of the enzyme. Sharma et al. (2001), refer to olive oil as an inexpensive and efficient component for lipase analysis and a good substitute for synthetic substrates, which are more expensive.

There was no significant difference in the results for enzymatic activity of the isolate G40 when grown in submerged culture in the bioreactor using olive oil, canola or grape seed oil. This result is satisfactory, as it suggests that any of these substrates can be used as alternative low-cost nutritional sources for lipase production.

The use of the Tween 80 emulsifier in the orbital shaker and in the bioreactor submerged culture assay showed better growth than in the assay without the use of the Tween 80 emulsifier. The Tween 80 in small amounts acts as a surfactant homogeneously dispersing the oils through the culture medium, making the lipids easily available to the microorganism. It may also increase cell permeability thereby increasing the secretion of several molecules across the cell membrane (Silva et al. 2005). According to Ramani et al. (2010), the addition of surfactants in the culture medium can increase both the activity and the stability of the enzyme. In larger quantities, this emulsifier becomes one of the lipid carbon sources available to the microorganism.

The molecular mass of lipase from bacteria of genus Acinetobacter is quite variable from 23 to $62 \mathrm{kDa}$. Our work shows a $35 \mathrm{kDa}$ mass for the enzyme. Studies have found molecular mass values of $32 \mathrm{kDa}$ for Acinetobacter calcoaceticus (Kok et al. 1995), $38 \mathrm{kDa}$ for Acinetobacter radioresistens strain CMC-2 (Ng et al. 1999), $37.2 \mathrm{kDa}$ for Acinetobacter sp. SY-01 (Han et al. 2003), 45 kDa in Acinetobacter radioresistens CMC-1 (Hong and Chang 1998), and $53 \mathrm{kDa}$ in Acinetobacter johnsonii (Wang et al. 2011). Uttatree et al. (2010) working with Acinetobacter baylyi found a lipase with molecular mass of the $30 \mathrm{kDa}$, smaller than the one observed in this work. According to Agobu et al. (2017), the variation in molecular weight could be a result of frame-shift mutations which results in insertion or deletion of the gene.

Peptone used as a source of nitrogen in this work is also an inducer of lipase production. According to Sharma et al. (2001), peptone and yeast extract are the best nitrogen sources for microbial lipases when compared to other sources such as meat extract, tryptone or wheat bran.

Environmental pressures are important factors for the expression of enzymes such as lipases by microorganisms. Highly contaminated environments, such as effluents with high fat and oil loads, have been shown to be suitable for the screening and isolation of bacterial species that produce these enzymes.

\section{REFERENCES}

ADRIO JL AND DEMAIN AL. 2014. Microbial Enzymes: Tools for Biotechnological Processes. Biomolecules 4(1): 117-139.

AGOBO KU, ARAZU VA, UZO K AND IGWE CN. 2017. Microbial Lipases: A Prospect for Biotechnological Industrial Catalysis for Green Products: A Review. Ferment Technol 6: 142.

ALFENAS AC. 1998. Eletroforese de isoenzimas e proteínas afins. Fundamentos e aplicações em plantas e microrganismos. Viçosa, Uuniversidade Federal de Viçosa, 574 p.

ALHAMDANI MA AND ALKABBI HJJ. 2017. Study on the activity and optimization of lipase-producing bacteria isolated from oil-contaminated soil. Indo - Asian J Multidisciplinary Res 3(1): 944-956.

ALMEIDA AF, DIAS KB, SILVA ACC, TERRASAN CRF, TORNISIELO SMT AND CARMONA EC. 2016. Agroindustrial wastes as an alternative for lipase production by Candida viswanathii under solid-state cultivation: purification, biochemical properties, and its potential for poultry fat hydrolysis. Enzyme Res 2016: $1-15$.

ANBU P, NOH MJ, KIM DH, SEO JS, HUR BK AND MIN HK. 2011. Screening and optimization of extracellular lipase by Acinetobacter species isolated from oil- 
contaminated soil in South Korea. Afr J Biotechnol 10(20): 4147-4156.

ANKIT M, YAGINIK SK AND PRANALI MKYS. 2011. Screening and temperature optimization for lipase producing bacteria from waste contaminated water. Asian J Biochem Pharm Res 1(1): 62-69.

BHOSALE H, SHAHEEN U AND KADAM T. 2016. Characterization of a hyperthermostable alkaline lipase from Bacillus sonorensis 4R. Enzyme Res 2016: 1-11.

COSTA HB. 2014. Desenvolvimento de processo para a purificação de bromelina a partir de resíduos de abacaxizeiro (Ananas comoosus var. comosus) cv. Vitória. Tese de Doutorado em Biotecnologia, Universidade Federal do Espírito Santo, Vitória, 150 p.

DANDAVATE V, JINJALA J, KEHARIA H AND MADAMWAR D. 2009. Production, partial purification and characterization of organic solvent tolerant lipase from Burkholderia multivorans V2 and its application for ester synthesis. Bioresource Technol 100(13): 3374-3381.

DHARMSTHITI S AND KUHASUNTISOOK B. 1998. Lipase from Pseudomonas aerugina LP602: biochemical properties and application for wastewater treatment. J Ind Microbiol Biotechnol 21: 75-80.

DORSCH M AND STACKEBRANDT E. 1992. Some modifications in the procedure of direct sequencing of PCR amplified 16s rDNA. J Microbiol Methods 6: 271279.

ESAKKIRAJ P, RAJIKUNAR M, PALAVESAM A AND IMMANUEL G. 2010. Lipase production by Staphylococcus epidermidis CMSSTPI isolated from the gut of shrimp Penaeus indicus. J Ann Microbiol 60: 37-42.

FEITOSA IC, BARBOSA JMP, ORELLANA SC, LIMA AS AND SOARES CMF. 2010. Produção de lipase por meio de microrganismos isolados de solos com histórico de contato com petróleo. Acta Sci Technol 32: 27-31.

FREEDONIA G. 2014. World Enzymes: Industry Study with Forecasts for $2017 \& 2022$. The Freedonia Group, 338 p.

GURURAJ P, RAMALINGAM S, GANESAN ND AND GAUTAM P. 2016. Process optimization for production and purification of a thermostable, organic solvent tolerant lipase from Acinetobacter sp. AU07. Braz J Microbiol 47(3): 647-657.

HAN SJ, BACK HB, YOON MY, SHIN PK, CHUNG CS AND SUNG MH. 2003. Expression and characterization of a novel enantioselective lipase from Acinetobacter species SY-01. Biochimie 85: 501-510.

HONG MC AND CHANG MC. 1998. Purification and characterization of an alkaline lipase from a newly isolated Acinetobacter radioresistens CMC-1. Biotechnol Lett 20: 1027-1029.

IQBAL AS AND REHMAN A. 2015. Characterization of lipase from Bacillus subtilis I-4 and its potential use in oil- contaminated wastewater. Braz Arch Biol Technol 58(5): 789-797.

KOBORI CN AND JORGE N. 2005. Caracterização dos óleos de algumas sementes de frutas como aproveitamento de resíduos industriais. Ciênc Agrotec 29(5): 1008-1014.

KOK RG, VAN THOR JJ, NUGTEREN-ROODZANT IM, BROUWER MBW, EGMOND MR, NUDEL CB, VOSMAN B AND HELLINGWERF K. 1995. Characterization of the extracellular lipase, LipA, of Acinetobacter calcoaceticus BD413 and sequence analysis of the cloned structural gene. Mol Microbiol 15: 803-818.

KOUKER G AND JAEGER KE. 1987. Specific and sensitive plate assay for bacterial lipases. Appl Environ Microbiol 53(1): 211-213.

LIU X AND KOKARE C. 2017. Microbial enzymes for use in industry. Biotechnology of Microbial Enzymes. Academic Press, p. 267-298.

MUSA H AND TAYO ACB. 2012. Screening of microorganisms isolated from different environmental samples for extracellular lipase production. J Appl Science 15(3): 179-186.

NG IS, TSAI SW AND CHEN SJ. 1999. Purification and characterization of extracellular lipase from Acinetobacter radioresistens CMC-2. J Chin Inst Chem Eng 30: 355-362.

NIYONZIMA FN AND MORE SS. 2014. Concomitant production of detergent compatible enzymes by Bacillus flexus XJU-1. Braz J Microbiol 45(3): 903-910.

NWACHUKWU E, EJIKE EN, EJIKE BU, ONYEANULA EO, CHIKEZIE-ABBA RO, OKOROCHA NA AND ONUKAOGU UE. 2017. Characterization and optimization of lipase production from soil microorganism (Serratia marcescens). Int J Curr Microbiol App Sci 6(12): 1215-1231.

OCHSENREITHER K, GLÜCK C, STRESSLER T, FISCHER L AND SYLDATK C. 2016. Production strategies and applications of microbial single cell oils. Front Microbiol 7: 1539.

ODEYEMI AT, ADERIYE BL AND BAMIDELE OS. 2013. Lipolytic activity of some strains of Klebsiella, Pseudomonas and Staphylococcus spp. from restaurant wastewater and receiving stream. J Microbiol Res 3(1): 43-52.

ORLANDELLI RC, SPECIAN V, FELBER AC AND PAMPHILE JA. 2012. Enzimas de interesse industrial: produção por fungos e aplicações. SaBios 7(3): 97-109.

PRATUANGDEJKUL J AND DHARMSTHITI S. 2000. Purification and characterization of lipase from psychrophilic Acinetobacter calcoaceticus LP009. Microbiol Res 155(2): 95-100.

QIAN Z AND CHUN-YUN ZG. 2009. Screening for lipaseproducing Enterobacter agglomerans for biodiesel catalyzation. Afr J Biotechnol 8: 1273-1279. 
RAMANI K, CHOCKALINGAM E AND SEKARAN G. 2010. Production of a novel extracellular acidic lipase from Pseudomonas gessardii using slaughterhouse waste as a substrate. J Ind Microbiol Biotechnol 37: 531-535.

RAMNATH L, SITHOLE B AND GOVINDEN R. 2017. Classification of lipolytic enzymes and their biotechnological applications in the pulping industry. Can J Microbiol 63: 179-192.

RODRIGUEZ JA, MATEOS, JC, NUNGARAY J, GONZÁLEZ V, BHAGNAGAR T, ROUSSOS S, CORDOVA J AND BARATTI J. 2006. Improving lipase production by nutrient source modification using Rhizopus homothallicus cultured in solid state fermentation. Proc Biochem 41: 2264-2269.

ROUSENAU F AND JAEGER K. 2000. Bacterial lipases from Pseudomonas: regulation of gene expression and mechanisms of secretion. Biochimie 82: 1023-1032.

SANTOS RR. 2012. Caracterização e aplicação de borras do refino de óleos vegetais para produção de lipase fúngica por fermentação no estado sólido. Dissertação de Mestrado em Ciência e Tecnologia dos Alimentos, Universidade Federal Rural do Rio de Janeiro, Seropédica, 83 p. (Unpublished data).

SHARMA P, SHARMA N, SHARMA P, PATHANIA S AND HANDA S. 2017. Purification and characterization of a halotolerant and thermotolerant lipase produced from a novel bacteria "Brevibacterium halotolerans PS4 |KX671556|" and its application in detergent formulations. Proc Indian Nat Sci Acad 83(3): 681-687.

SHARMA R, CHISTI Y AND BANERJEE UC. 2001. Production, purification, characterization, and applications of lipases: Research review paper. Biotechnol Adv 19: 627-662.

SILVA WOB, MITIDIERI S, SCHRANK A AND VAINSTEIN MH. 2005. Production and extraction of an extracellular lipase from the entomopathogenic fungus Metarhizium anisopliae. Process Biochem 40: 321-326.

SOOCH BS AND KAULDHAR BS. 2013. Influence of multiple bioprocess parameters on production of lipase from Pseudomonas sp. BWS-5. Braz Arch Biol Technol 56(5): 711-721.

TURNER S, PRYER KM, MIAO VP AND PALMER JD. 1999. Investigating deep phylogenetic relationships among cyanobacteria and plastids by small subunit rRNA sequence analysis. J Eukaryot Microbiol 46(4): 327-338.

UGRAS S AND UZMEZ S. 2016. Characterization of a newly identified lipase from a lipase-producing bacterium. Front Biol 11: 323-330.

UTTATREE S, WINAYANUWATTIKUN P AND CHAROENPANICHJ.2010. Isolation and characterization of a novel thermophilic-organic solvent stable lipase from Acinetobacter baylyi. Appl Biochem Biotechnol 162: 1362-1376.

VISHNUPRIYA B, SUNDARAMOORTHI C, KALAIVANI M AND SELVAM K. 2010. Production of lipase from Streptomyces griseus and evaluation of bioparameters. Int J Chem Tech Res 2(3): 1380-1383.

VITORINO LC AND BESSA LA. 2017. Technological microbiology: development and applications. Front Microbiol 8: 827.

WANG HK, SHAO J, WEI YJ, ZHANG J AND QI W. 2011. A novel low-temperature alkaline lipase from Acinetobacter johnsonii LP28 suitable for detergent formulation. Food Technol Biotechnol 49: 96-102.

WINKLER UK AND STUCKMANN M. 1979. Glycogen, hyaluronate, and some other polysaccharides greatly enhance the formation of exolipase by Serratia marcescens. J Bacteriol Mycol 138(3): 663-670. 